\title{
LEGAL TREATMENT OF FOREIGN AND DOMESTIC CREDITORS
}

\author{
Kurt H. NadelmanN*
}

"There will always be found in every State a large mass of politicians, who will deem it more safe to consult their own temporary interests and popularity, by a narrow system of preferences, than to enlarge the boundaries, so as to give to distant creditors a fair share of the fortune of a ruined debtor." International trade has learned through costly experience the truth of this statement of Story. ${ }^{1}$

Differentiation in the treatment of the resident and the distant creditor is an old ill. There are few countries in which there have not been tendencies at some time to favor the local creditor. Differentiation is still practiced in various countries. The fear of its consequences, as well as the security measures adopted in protection, hamper international trade.

The local creditor obtains preference in different ways. They are not always easy to recognize and not generally known. Insufficient documentation has been a major handicap in dealing with the subject of discrimination. A presentation of some types of existing inequalities in the treatment of the foreign and the domestic creditor may be helpful in efforts to overcome differentiation.

\section{Creditor Equality}

Questions of discrimination against the distant creditor do not normally arise when the debtor's assets suffice to pay all his debts. Eventually, all creditors recover their claims, whether under the priority system: first come first served, which govern executions in the Germanic ${ }^{2}$ and Anglo-Saxon ${ }^{3}$ countries, or the equality system, applied in the other countries, ${ }^{4}$ where the individual creditor does not acquire priority rights by attachment or garnishment.

When the assets are insufficient to pay all creditors, application of the priority system leads to injustice. Henry Brinklow in his "Complaynt of Roderick Mors," published in 1542 shortly before Henry VIII introduced the first English bankruptcy act, called "the rich" the beneficiaries of the priority system: "For lyghtly the rich

* Dr. Jur., Freiburg in Breisgau; Licencié en droit, Paris; Research Fellow, r941-I945; Lecturcr, Law School, University of Pennsylvania. Formerly, Judge, District Court, Berlin, Germany. Co-editor, Annales de Droit Commercial Français, Etranger et International: Supplement sur le Droit ComparE DEs Faillites. Consultant, Foreign Economic Administration, 1944-1945. Contributor to American and foreign legal periodicals.

12 Story, Commentaries on the Constitution of the United States (1833) $\$ 1107$.

2 See Fragistas, Das Praeventifprinzip in der Zwangsvollstreckung (1931).

${ }^{3}$ Cf. Glenn, Llouidation (1935) 9; Sturges, A Proposed State Collection Act (1934) 43 Yale L. J. 1055.

E.g., Codes of Civil Procedure of France $\$ \$ 6 \mathrm{ro}$, 656; Belgium \$\$609, 656; Italy \$\$646, 651; Netherlands $\$ \$ 457$ ff. 
have the first knowledge of soch things."5 A century later, Charles II, in the introduction of the equality rule in Scotland, referring to the needs of trade and traffic with other nations, emphasized the harm done to distant creditors, "in regard they live at distance or upon other occasions are prejudged and preveened by the more timeous diligence of other creditors."

Today, when a debtor is insolvent, bankruptcy laws everywhere provide for the equal distribution of the assets among all creditors. Generally, no differentiation is made between foreign and distant creditors when all assets are located in the country of the bankruptcy proceeding. Foreign creditors were not always admitted on equal terms, however. Mediaeval laws in Swiss Cantons $^{\top}$ and German cities, ${ }^{8}$ for example, and early statutes in the Plantations ${ }^{\ominus}$ gave the local creditors a right of priority of payment. This often led to retaliation. Even in 1784 , Louis XVI was obliged to order measures of retaliation against Swiss Cantons in order to obtain equal treatment for French citizens in Switzerland. ${ }^{10}$

Difficulties which a distant creditor may still encounter in a bankruptcy where all the assets are in the country of the proceeding, are of a practical rather than a legal nature. Sometimes notification of the proceeding is belated ${ }^{11}$ and insufficient time is granted for the proof of claims. Only recently, the International Chamber of Commerce stressed the need for better notification. ${ }^{12}$ A few treaties deal especially with this subject. ${ }^{13}$ Prompt notification has become particularly important in reorganization and arrangement proceedings to enable the distant creditor to vote on the plan. ${ }^{14}$ Belated notification could be avoided with the present means of communications if use of the most rapid way were prescribed..$^{14 *}$

\footnotetext{
${ }^{7}$ See Heussler, Die Bildung des Concursprozesses nach schweizerischen Rechten (1858) 7 ZEITschruFT FÜR SCHWEIZERISCHES RECHT II, 200.

${ }^{8}$ See I Stobe, Handbuch des deutschen Privatrechts (1871) 263.

${ }^{\circ}$ See I Grahame, History of the United States of Axserich (1856), App. I, 560; Noei, History OF THE BaNRRUPtCy LAW (1919) 44.

${ }^{10}$ Sec MEILI, EIN historisches IN TERMeZzo zWISChEN FRANkreich UND deR SCHWEIZ BETR. DIE INTERnationale Stellung der Konkursglaeubiger (1909); Lévy-Bruhl, Recherches sur la réglementation internationale des faillites au ise siècle (I938) RevUe CrItIQUe de DroIt INTERnational 175.

${ }^{11}$ See, e.g., the Cotesworth and Powell case (Great Britain v. Colombia), 2 Moore, Internatronal Arbitrations (1898) 2050, 2083; Freeman, Denial of Justice (1938) 290.

${ }^{12}$ International Chaxiber of Commerce, Resoluttons of the Xth Congress (1939) i7; (1939)

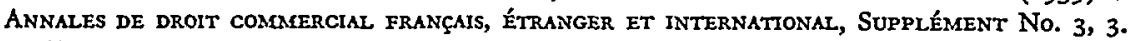

${ }^{13}$ Notification of the Consulate prescribed in the treaties of Czechoslovakia with Lithuania, April 24, 1931, \$23, 126 League of Nations Treaty Series 279, and Poland, Feb. 10, 1934, \$1 I, I78 League of Nations Treaty Series 173 .

${ }^{14}$ Silence, in some laws, counts as a vote for the plan: Percerou and Nadelamann, Changes in Bankruptcy Legislation (General Report, 1937, The Hague) (r937) AnNales de droit commercins Franças, Etranger et internattonal 18 i, 188; (1938) i2 J. N. A. Ref. Bankr. 68, 71 (trans.).

2ia Compare, e.g., the law of Brazil, which prescribes telegraphic notification of distant creditors, with the Argentine law, under which a simple letter is sufficient. Cf. Zeballos in 2 Weiss, Manual de Derecho Internacional Privado (2d ed. in Spanish, 1928) 711, 714.
} II8.

5 Holdsworth, History of English Law (1925) 232.

- Act for Ordering the Payment of Debts, x66r, c. 344, Scors Statutes Revised 1424-1707 (1908) 


\section{Legal Discrimination}

The status of the law is wholly unsatisfactory, from the viewpoint of creditor equality, when the assets of the debtor are not all in the country of the bankruptcy proceeding. This situation is common in international trade. Equality is not always assured in such "international" bankruptcy cases.

When the trustee in bankruptcy appointed at the domicile of the debtor can collect the foreign assets, ${ }^{15}$ there are no questions of differentiation. They arise in various ways when he cannot collect or conditions are attached to the transfer of the assets.

Assets in a country which has the priority rule for executions and does not recognize the rights of a foreign trustee in bankruptcy, are subject to the race of diligence. Normally, the local creditor has better knowledge of the local assets and can be quicker in attaching them. Creditors from the country where the bankruptcy has been declared, may be required to obtain permission first from the trustee to prosecute abroad. This gives the local creditor an advantage over distant creditors. ${ }^{10}$ The local creditor has what has been termed an "underhand" preference. ${ }^{17}$ To eliminate the inequality, most countries provide that a local bankruptcy may be declared for the equal distribution of the local assets of non-resident debtors.

Germany is one of the countries which do not generally provide for this possibility. Under German law, executions may be levied on local assets regardless of a foreign bankruptcy declaration. ${ }^{18}$ Only when there is a business branch or a rural estate in Germany, may a local bankruptcy take place. ${ }^{19}$ The Nadeshda case furnishes an illustration. A Russian corporation had been declared bankrupt in Russia. The German branch was declared bankrupt in Germany shortly thereafter. The corporation had a debtor for substantial amounts in Germany. The Russian and the German trustee in bankruptcy agreed that half of the debt should belong to the Russian and half to the German bankruptcy estate. Shortly afterwards, a German creditor who had proved his claim in the German bankruptcy, garnished the part of the debt which, under the agreement, belonged to the Russian estate. The German Supreme Court, in a decision rendered during the First World War, ${ }^{20}$ upheld the garnishment. Had there been no bankruptcy declaration in Germany, argued the court, the creditor could have garnished the whole debt; the trustee agreement had freed one half for individual execution. It is obvious that the chances are not equal for the local and the distant creditor under this system.

${ }^{15}$ Cf. Nadelmann, International Bankruptcy Law: Its Present Status (r944) 5 U. op TonoNro L. J. 324, i 8 J. N. A. Ref. Bankr. 104, (1945) 67-72 Journal du Droit International 64; 7 Travens, Droit Commercial International (I: 1935, II: 1936); Valensi, Faillite, in 8 REpertoire de Droit INTERNATTONAL. (I930) 286.

${ }^{10}$ See, e.g., Boden \& Haac v. Lovell, 203 Fed. 234 (I9r3), where the foreign creditors were slower than the local in the race for assets of an American bankrupt in Germany.

${ }_{17}^{17}$ Lowell, Conflict of Laws as Applied to Assignments for Creditors (1888) r Harv. L. REv. $259,266$.

${ }^{28}$ Bankruptcy Code, $\$ 237,24$ Commercial Laws of the Worlo (Am. ed. 1909) 395; 2 Jaxoer, KOMMENTAR zUR KONRURSORDNung (7th ed. 1936) 968.

${ }^{10}$ Bankruptcy Code, $\$ 238$, supra note 18 .

${ }^{20}$ Reichsgericht, Nov. 7, 1916, 89 EntscheidungeN in ZivilsacheN 181 . 
A situation of the same type is encountered in connection with arrangements. For example, a debtor obtained in his country a composition in an arrangement proceeding. The proposal made by the debtor was based on all his assets. Later, a foreign creditor who had participated in the arrangement proceeding, attaches assets in his own country for the discharged part of his claim. Courts in various Central-European countries have upheld such attachments, even when the creditor had voted for the arrangement. ${ }^{21}$ The Supreme Court of Czechoslovakia, in an instance involving an arrangement made in a proceeding in Germany, ${ }^{22}$ supported its decision with the argument that there was no guaranty that German courts would respect a Czechoslovakian arrangement in a reversed situation. Such practices, of course, jeopardize arrangement proceedings. ${ }^{23}$

In the United States, under the federal bankruptcy act of 1898 , it is possible to obtain a local bankruptcy declaration against non-resident debtors with assets in the United States; ${ }^{24}$ in such a bankruptcy all creditors are admitted equally. ${ }^{25}$ This possibility is not mentioned in the note on the Umbreit case published in the Journal du Droit International ${ }^{26}$ where it is asserted that under American law local creditors hold a priority over creditors from abroad. ${ }^{27}$

In that case, Disconto Gesellschaft v. Umbreit, ${ }^{28}$ a German subject, indebted to a German bank, absconded to the United States. He was declared bankrupt in Germany. The German bank discovered assets in a bank in Wisconsin and garnished them. The bankrupt had become indebted in Wisconsin to a local lawyer who attached the same funds. The local creditor contested the right of the German bank to have its prior attachment given priority over his later attachment. The German bank had intended to transfer the funds for distribution to the German trustee in bankrupcy. The Wisconsin Supreme Court held for the creditor in Wisconsin. According to the court, it was the duty of the state to protect its citizen by preventing the removal of the assets found within the state in order that he might be able to satisfy his claim in the state. ${ }^{29}$ The Supreme Court of the United States ${ }^{30}$ affirmed

${ }^{21}$ See Nussbaum, Deutsches internationales Privatrecht (I932) $455-56$ note 4 .

${ }^{22}$ Sup. Ct., April 23, 1936 (1937) Zeitschrift für Osteuropaeisches Recht 255, noted by Nadelmann in (1938) Nouvelle Revue de Droit International RRIVÉ 427.

${ }^{33}$ Cf. Nadelmann, The Recognition of American Arrangements Abroad (1942) go U. of PA. L. Rev. 780, (I 943) 29 Revista Júnídica ARgentina LA Ley 888 (trans.).

34 BankRuptcy Act, \$2 (a) (1), 30 STAT. 545 (1898), (I4th ed. I940) \$2.I5; In re Neidecker, 82 F. (2d) 263 (C. C. A. 2 d, 1936 ).

${ }^{25}$ BankRuptcy Act, $\$ 65$ (d), 30 Stat. 563 (I898), il U. S. C. \$I05; 3 Collier, Bankruptcy (14th ed. 1940) \$65.05. Cf. Mack, J., in In re Aktiebolaget Kreuger \& Toll, 20 F. Supp. 964, 965 (1937).

26 (zgo8) Journal du Droit International 1322.

${ }^{37}$ Repeated in, e.g., 8 Répertoire de Droit International (1930) 379 No. 7i4; Despagnet-De Boeck, Precis de Droit International Privé (5th ed. ig09) rig9; Caicedo Castilla, Manual de Derecho Internacional Privado (3d ed. 1944) 377 .

${ }^{28} 127$ Wis. 651, 106 N. W. 821 (1906).

${ }^{30}$ Cf. Roosevelt, J., in In the matter of Coates and Hillard, I3 Barb. 452 (N. Y. I852): "Our courts insist, and rightfully, that the administration of the debtor's assets, within our limits where our own citizens have an interest in them, shall be here and not elsewhere. ... We take this stand, not to defeat, but to insure justice; not to rob the foreign creditor, but to protect the rights of all the creditors. 
the decision, holding that this policy did not violate the "due process of law" clause of the Constitution of the United States. The German Government protested to the United States Government, threatening with retaliation. ${ }^{31}$

The decision in the Umbreit case enabled the local creditor to obtain more than his equal share in the distribution of the assets of the bankrupt. This result was due to the faulty handling of the case by the German bankruptcy administration. If instead of trying to remove the assets from the United States, the German creditors had secured a bankruptcy declaration in the United States, the local assets would have been equally distributed among all creditors, local and distant.

There are many instances where it is more desirable to have the foreign assets distributed in a local proceeding, if available, than to claim them for the principal bankruptcy. Under the law of Austria, Czechoslovakia, Yugoslavia, and Hungary, for example, a foreign trustee in bankruptcy may receive the local movable assets, but attachments made up to the filing of the request for transfer must be satisfied. ${ }^{32}$ The creditors thus still have time to attach after the debtor has become insolvent, and the local creditors are usually the beneficiaries. By a local bankruptcy adjudication the attachments can be avoided and equality reestablished.

Similar problems arise when an exequatur by a local court is needed to obtain recognition of the effect of a foreign bankruptcy declaration. As the exequatur is without retroactive effect, the estate is unprotected until the grant of the exequatur. ${ }^{33}$ An illustration is the Richer case before the French courts. A resident of France had a claim in a bankruptcy in Mauritius. Some time after the bankruptcy adjudication in Mauritius, he himself became indebted to the estate. Neither under the bankruptcy law of Mauritius nor of France, would the set-off have been allowed between debt and claim. As no exequatur had been procured in France, the French Supreme Court ${ }^{34}$ held that the set-off had taken place and was valid.

Under the law of Brazil, which permits collection of the local assets after the grant of an exequatur, creditors residing in Brazil are allowed to levy execution on the local assets notwithstanding the exequatur if they had begun legal proceedings prior to the exequatur. ${ }^{35}$ This would not be permitted were bankruptcy declared in Brazil. As the advantage is accorded only to residents of Brazil, this is a case of open differentiation against non-resident creditors. ${ }^{36}$

We do it to enable our courts to marshal the assets, and to correct, if necessary, inequalitics abroad, by proper compensating adjustments at home."

${ }^{30}$ Disconto Gesellschaft v. Umbreit, 208 U. S. 570 (1907), 3 Hackworth, Digest of Internatronat LAw (1942) 570 (excerpts).

32 Dep't of STate, Foreign Relations of the United States (1910) 518.

${ }^{32}$ References in Nadelmann, loc. cit. stupra note 15 , at 329,330 .

${ }^{33}$ Cf. Allgemeine deutsche Credit Anstalt v. Fuld et Cie. et Schiff, Court of Appeal, Paris, June I, 1906, Dalloz Jurisprudence, x909, II, 9; (1907) Journal du Droir INTERnational 135 (attachment before exequatur).

${ }^{34}$ Synd. Richer et Cie. v. Detouche, Cour de Cassation, June 26, 1905, Sirey, 1905, I, 433, Dalloz Jurisprudence, $1905, \mathrm{I}, 513$, (1905) JourNal, du Droit INTERNATIONAL IO14.

${ }^{35}$ Bankruptcy Law No. 5746 of 1929, $\$ 160$ (4), 8 Carvalho de Mendonģa, Tratado de Dinetro CONAMERCtal Brasileiro (I937) \$1340; Valladao, Force exécutoire des jugements étrangers au Brésil (r93i) Journat dU Drotr InTERnatTonat 590, 606.

${ }_{26}$ Strongly criticized in 3 Miranda Valverde, A falencis no direito grasizejro (1934) 374. 
Particularly intricate is the subject of attachments made in the period immediately preceding the foreign bankruptcy adjudication. All bankruptcy laws declare attachment liens void when obtained in the "critical period" before the bankruptcy adjudication. The extent of this period differs in each country. When foreign trustees in bankruptcy are permitted to collect local assets, as in England, the question arises how to deal with such attachments. In Galbraith $v$. Grimshaw, ${ }^{37}$ an English creditor had attached assets of his Scottish debtor in England shortly before the debtor was declared bankrupt in Scotland. The attachment was void under Scottish law and would have been void under English law, had bankruptcy been declared in England. The House of Lords upheld the attachment. In 1764 , in the famous case Solomons $v$. Ross, ${ }^{38}$ an English court had permitted a Dutch trustee in bankruptcy to collect assets attached by an English creditor after the debtor had become insolvent, but before he was adjudged bankrupt in Holland.

Institution of local bankruptcy proceedings is a means to secure equal treatment for all creditors, but it has been used also to give priority to the local creditors. The Prussian Code of Civil Procedure of I793 provided that when bankruptcy was declared abroad and assets were located in Prussia, a local bankruptcy had to take place in Prussia. In that bankruptcy, only the creditors in Prussia could participate; a surplus was at the disposal of the foreign court. ${ }^{39}$ Because of difficulties with other countries, the Code was amended five years later and non-resident creditors were admitted unless it could be proved that their country discriminates against foreign creditors. ${ }^{40}$

The rule of the Prussian Code, without the amendment, is still found in some countries in South America. The Commercial Code of the Province of Buenos Aires of $18599^{41}$ which became the Commercial Code of Argentina in 1862, provided that local creditors should be paid before the other creditors in the case of concurrent bankruptcies. This is still the law in Argentina, ${ }^{42}$ and it has been adopted by Uruguay, ${ }^{43}$ Paraguay, ${ }^{44}$ and, recently, Peru. ${ }^{4 \overline{5}}$ The provision reads: "The bankruptcy also declared by the courts of the Republic shall not take into consideration the creditors belonging to the foreign bankruptcy, except if a surplus remains after payment in full of the creditors in the Republic."

${ }^{37}$ Galbraith v. Grimshaw, [1910] A. C. 508. It prompted a change in the Scottish bankruptcy law to secure recognition: Dicey, Conflict of LAws (5th ed. by Keith, I932) 369 note (u).

${ }^{38}$ I H. Bl. ${ }^{3} \mathrm{I}$ note $\left(\mathrm{I}^{64}\right)$ ). CF. Nadelmann, Solomons v. Ross and International Bankruptcy Law (1946) 9 Mod. L. Rev. (No. 2).

${ }^{30}$ Code of Civil Procedure, 1793 , pt. I, tit. 50, $\$ 665,2$ Levi, Commercial Law of the Worlo (ז852) 357 .

to Appendix to the Code, $\$ 379$, added by decree of Sept. 24, I798, Novum Corpus Construtumonum Prussico-Brandendurgensium (I798) 1758.

11 Sec. 1531 of the Code. The drafters may have drawn from the Prussian Code which was reproduced without the amendment in SAINT-Joseph, Concordance entre les Codes de Commerce Etrangers et le Code de Comarerce Français (1851) 120.

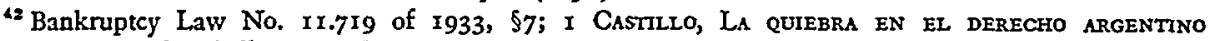
(1940) \$103. Cf. Zeballos in 2 Weiss, Manual de Derecho Internacional Privado (I912) 652, note.

" Comaercial Code, \$1577; Scarano, Tratado de la quiebra (r939) 210.

" Commercial Code, $\$ 1383 ; 2$ Sapena Pastor, Derecho internactonal privado (x945).

"B Bankruptcy Law No. 7566 of 1932, \$26 (2); SANChez Palacios, Ley procesaz de Quiebras (1939) 20. 
Under this rule, non-resident creditors are prevented from receiving their equal share whenever there are two bankruptcies, one in the country and one abroad. Almost since its inception, the rule has been denounced by leading Argentine jurists, among them Calvo. ${ }^{46}$ More recently, Dr. Carlos Alberto Alcorta in an addressi warned his countrymen that maintaining the rule might lead to the same consequences that a Swiss Canton experienced at the hand of Louis XVI. ${ }^{48}$

Local commentators of the rule ${ }^{49}$ have stressed the need for protection of the local creditor against similar practices abroad. This does not justify application of the rule against creditors from countries which observe the principle of creditor equality. ${ }^{50}$ It was said recently that without such a rule local creditors might lose their share in the assets abroad because of foreign exchange regulations. ${ }^{51}$ Under the principle of marshalling, known in all legal systems, ${ }^{52}$ creditors who have received payments abroad, are not paid until the other creditors have received the same proportion of their claim out of the local assets. Marshalling, therefore, gives the local creditor every possible protection.

One of the priority rules based on factors other than residence is that which gives preference to branch creditors when the local branch of a foreign enterprise is declared bankrupt. Mexico's new bankruptcy law provides that the bankruptcy in Mexico of a branch of a foreign, enterprise affects the assets in Mexico and the debts resulting from operations of the branch. ${ }^{53}$ Only creditors of the branch thus share in the Mexican assets. ${ }^{54}$

A ruling of the Swiss Supreme Court in the matter of Peter ${ }^{65}$ had the same effect. The branch in Switzerland of an Austrian textile firm had been declared bankrupt in Switzerland. Creditors who were not creditors of the branch were not allowed to prove in the bankruptcy. The court relied on a provision in the law $w^{56}$ under which creditors of a non-resident debtor may seek execution in Switzerland only if the debtor has a branch in Switzerland and the debt results from trans-

${ }^{16} 2$ Calvo, Droit International (5th ed. 1896) No. 9 it in fine. Cf. Quesada, Estudios somine QUIEBRAS (1882).

${ }^{47}$ Régimen internacional de la quiebra (1924) I4 JuRusprudencta ARgENTiNa 130, 134, reproduced in 4 Vico, Curso de derecho internacional privado (I927) 115 . See also: Arguas y Lascano, TruTADO DE DEREChO INTERNACIONAI PRIVAdo (I926) 3I5; 2 ORIONE, LEY DE QUIEBRAS (I935) 33 T.

${ }^{4}$ Stupra page 697 .

${ }^{20}$ E.g., Ardiengol, Fundamentos Y critica de la ley de quiebras (2d ed. 1914) 218; 9 Maragarriga, Codigo de Comercio ( 3 d ed. 1926) 64.

${ }^{50}$ Cf. Nadelmann, Principales problemas del derecho internacional de quiebras in 2 MeMORIA DE LA Tercera Conferencia de la Federacion Interamericana de Abogndos (1945) 211. Cf. the amendment to the Prussian Code of 1793, stipra.

to Rivarola, Tratado de derecho comerctar argentino (i940) \$I 409 .

52 U. S. BANKRUPTCX ACT, $\$ 65$ (d), 30 STAT. 563 (1898), II U. S. C. $\$ 105,3$ CoLliek, BANKRupTcy (I4th ed. I940) \$65.05. English law: Banco de Portugal v. Waddell, 5 App. Cas. I6r (1880). French law: App. Paris, May II, 1927, (1928) Journal du Droit Internattonat, 654. CF. stpra note 29.

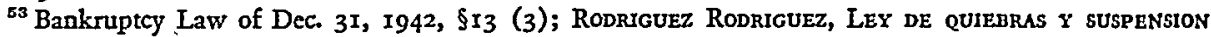
DE PAGOS (I943) 29.

54 Strongly criticized by Arce, Manual de derecho internacional privado mexicano (1943) $38 \mathrm{r}$.

¿s Bundesgericht, April 30, 1914, Amtliche Sammlung, 40.III, 123.

${ }^{56} \mathrm{Law}$ on Executions and Bankruptcy of $1889, \$ 50$. 
actions with the branch. The court held that the legislator had thus intended to reserve the assets in Switzerland for the creditors of Swiss branches. ${ }^{57}$

Normally, a branch has no distinct personality. It has no assets of its own, nor is there a legal relationship between branch debts and local assets. These assets may have no connection whatsoever with the operation of the branch. Grant to branch creditors of priority rights on local assets violates the principle of creditor equality. Maintenance of large funds in countries with such a priority rule may be detrimental to the creditors generally.

Branches sometimes are a distinct entity. In banking and insurance, for example, where supervision is necessary in the public interest, legislation in many countries regulates the admission and administration of branches of foreign establishments making the branches separate entities with separate assets and debts. By express provision ${ }^{58}$ or implicitly, ${ }^{59}$ branch creditors then have a priority on the branch assets.

\section{Separate Establishments}

The case of a debtor with distinct and separate establishments has long played an important role in the matter of priorities. ${ }^{60}$ Under Roman law, when a slave operated distinct businesses for his master, the creditors of each business were considered separately in the distribution of the assets; for "credit was given more to the business than to the business owner." ${ }^{11}$ The rule disappeared with the modern codifications. Nowhere does the law prescribe separate consideration of the creditors if a debtor has distinct and separate establishments in the country. "The whole property of the debtor is a common pledge for all his creditors." ${ }^{\prime 2}$

In private international law, the rule is still found in South America. In Brazil, when a debtor domiciled abroad has two distinct and separate establishments, one abroad and one in Brazil, the creditors with claims payable in Brazil have a priority in the bankruptcy of the establishment there. ${ }^{63}$ Determination of a "distinct and separate" establishment lies with the local court and may have grave consequences depending upon the respective financial status of the domestic and the foreign establishment. $^{\text {(4 }}$ Courts outside Brazil may, because of the provision in the Brazilian

\footnotetext{
${ }^{67}$ Bundesgericht, April 14, 1936, Ampr.iche Sammunng, 62.III, 74, notes the possibility that the priority right may not be recognized abroad (matter of the Bank of London, Ltd.).

${ }^{i s}$ See, e.g., the banking laws of Chile (\$13), Peru (\$33), Mexico (\$227) now replaced by the new bankruptcy law, supra note 53 .

${ }^{20}$ See Moscow Fire Ins. Co. v. Bank of New York \& Trust Co., 280 N. Y. 286, 309, 20 N. E. (2d) 758 (1939), aff'd 309 U. S. 624 (1940), for the construction of the New York Insurance Law. When a deposit is required, creditors become secured to the extent of the special fund. Matter of People (Southern Surety Co.), 282 N. Y. 54 (1939); (1940) 88 U. of PA. L. REv. Ior 8.

${ }^{\circ}$ Discussed in Nadelmann, Foreign and Domestic Creditors in Bankruptcy Proceedings-Remnants of Discrimination? (r943) 9r U. of PA. L. REv, 601, 6r3 ff.

${ }^{1}$ D. $14 \cdot 4 \cdot 5 \cdot 15$.

${ }^{02}$ Code Napoléon, $\$ \$ 2092,2093$.

${ }^{03}$ Bankruptcy Law No. 5746 of 1929, $\$ 16 r$, supra note 35 . Cf. Code of Civil Procedure of 1939, 5788; Tenorio, Direito Internacional Privado (1942) \$532.

'Cf. App. Paris, May II, I927, (I928) Journal DU Drolt International, 654 (matter of the Banque Française pour le Brésil).
} 
law, think that they, too, can refer Brazilian creditors to the assets in Brazil if they consider the establishment there as a "distinct and separate" one.

Peru's bankruptcy law of 1932 contains a provision related to the separate establishment concept. Debts contracted outside Peru are admitted on an equality basis to the extent to which the money has been employed in an enterprise in Peru. Credits invested in a foreign enterprise of the bankrupt are paid after full payment of all other claims. ${ }^{65}$

The separate establishment doctrine has been used also in bankruptcy treaties. Both the Montevideo treaties and the Bustamante Code of Private International Law distinguish between a debtor who has only one establishment and a debtor with different independent establishments in different countries. Under the Bustamante Code, when a debtor has divers "economically entirely separate commercial establishments" in more than one country, there may be as many bankruptcies or arrangement proceedings as establishments. Otherwise, the court of the domicile of the debtor has exclusive jurisdiction and the adjudication has full effect everywhere. ${ }^{66}$ The system of Montevideo is more involved.

In the Montevideo treaty of International Commercial Law of $\mathrm{I889}$, ratified by Argentina, Paraguay, Peru, Uruguay, Bolivia, and Colombia, a distinction is made between a debtor with two or more "independent commercial houses" in different countries and other debtors, including those who "trade occasionally in another country, or maintain there agencies or branches operated for account and under the responsibility of the main house." In the first case, the court of the seat of each independent house has bankruptcy jurisdiction. Otherwise, only the court of the commercial domicile of the debtor has jurisdiction. ${ }^{67}$ When bankruptcy has been declared in one country and assets are also located in another country, creditors with claims payable in that country may ask for another bankruptcy there. The proceedings then are conducted separately. ${ }^{68}$ The authorities disagree upon whether the right to ask for a separate bankruptcy applies in every case, or only when there is an independent house in the country. ${ }^{69}$ It is also controversial whether in the case of independent houses the local assets shall be separated for distribution purposes even when no separate bankruptcy is declared. ${ }^{70}$

The system of the treaty of 1889 has been replaced by another system in the new treaties of Montevideo signed in I940 at the Second South American Congress

\footnotetext{
${ }^{\text {os }}$ Bankruptcy Law No. 7566 of $1932, \$ 26$ (3), stupra note 45.

${ }^{68}$ Bustamante Code, $\$ \$ 414,415,86$ League of Nations Treaty Series 362 , The International Conferences of American States, r889-1928 (r931) 367. Cf. Bustaminte i Sirven, Manual de Derecio Internacional Privado (3d ed. 1943) No. 262.

${ }^{67}$ Sections 35,36 of the treaty, Report of the International American Congress (1890) 876; (1897) Journal du Droit International 900; 2 Romero del Prado, Manual de Derecho InterNacional Privado (1944) 577.

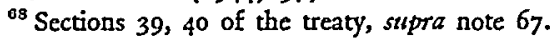

${ }^{60}$ See discussion, March 15, 1940, at the Second South American Congress of Private International Law, Montevideo, r939-1940, in the Commission on International Commercial Law. Actss DE LA REunion de Jurisconsultos, Montevideo (Segunda Etapa), Documentacion provisoria, Comiston de DEREcho COMERCIAL INTERNACIONAL, ACTA No. 3.

${ }^{\text {I0 Ibid. }}$
} 
of Private International Law. Creditors now have a right of priority of payment out of the assets in the country in which their claim is to be paid, whether or not there are independent houses, and whether or not the bankruptcy is conducted in a single or in several proceedings. ${ }^{71}$ The place of payment gives a right to priority of payment out of the local assets in all cases. The "place of payment" distinction, used in the "independent house" system as an auxiliary to separate the claims, is made the basis of a system itself.

The argument made at the Conference in support of the new system was that "in considering the status and the possibilities of payment of a prospective partner to a business transaction one takes into account exclusively the rights and debts the person has in the country where the contract is made, not those which he may have in other countries."72 One would think that this reasoning ${ }^{73}$ is conceivable only in the "independent house" situation where it has been used since the times of the Roman law. The possibility that the assets may be in another country when the debt becomes due, is too obvious to be disregarded. The basis for any credit system is shaken if the guaranty given by the whole estate is relinquished for a speculation on assets that may be found in the country where payment can be claimed. The debtor himself can determine what shall be paid by transferring assets from one country to another before the bankruptcy declaration. As there is no relation between local assets and local debts, except in the case of independent houses, it is impossible to determine the assets which should be in any one country.

At the Conference, the new rule had been introduced by the delegate from Uruguay $^{74}$ and was adopted contrary to the wishes of the delegates from Argentina. ${ }^{75}$ Since the Conference, adverse criticism has been expressed not only in Argentina, ${ }^{76}$ but also in Uruguay ${ }^{77}$ where a comprehensive study of the "doctrine of Montevideo" and the treaties of 1889 and 1940 has been published. ${ }^{78}$ The events

${ }^{71}$ Treaty of International Commercial Law, $\$ 48$ (2) : nd Treaty of International Law of Civil Procedure, $\$ 20$, signed at the Second South American Congress on Private International Law; for translations, see 37 AM. J. Int. L. Supp. 95, 120, 139. CE. 2 Romero del Prado, op. cit. supra note 67, at 580 and 962.

${ }^{73}$ Dr. Vargas Guillemette of Uruguay, July 25, 1939, at the Commission on International Procedural Law: Actas de la Reunion de Jurisconsultos, Montevideo (Primera Etapa), Documentacion Provisoria (1940), Comision de Derecho Procesal Internacional, Acta No. 4, 26; idem, August i, r939, at the Commission on International Commercial Law: ibid. Comision de Derecho Comercial InterNACionat, ACTa No. 7, 57.

${ }^{73}$ Cf. Carrio, Apuntes de derecho internacional privado (Montevideo, 19i1), 264.

11 Stipra note 72 .

${ }^{76}$ See Dres. Ruiz Moreno and Bollini Shaw, July 25, 1939, Actas supra note 72; Dr. Gonzales Gowland, March 15, 1940, at the Commission on International Commercial Law: ACTAS DE LA REunioN DE Jurisconsultos, Montevideo (Segunda Erapa), Doccimentacion Provisoria (1940), Comision de Derecho Comercial Internacional, Acta No. 3.

${ }^{70} 2$ ROMERo DEL Prado, op. cit. stipra note 67 , at 585 and 963 ; Videla Aranguren, El concurso civil de acreedores en el Congreso de Montevideo 1939/1940 (I94) Revista Argentina De Derecho InTERNAcionar 342; idem, Las quiebras en el Congreso de Montevideo 1939/1940 (1942) REvasTa ARGENtins de Derecho Internactonal 450; idem, Note (I943) 29 Revista Juridica Argentina La Ley 902, note (a).

${ }^{77}$ Alfonsin, Quiebras, La Doctrina de Montevideo y zos Tratados de i889 y 1940 (Montevideo, 1943) $\times 32$.

${ }^{78}$ Only Uruguay has so far ratified the new treaties (Law No. 10.272 of 1942). 
of Montevideo show that the desire for a local priority rule is still strong in South American countries. These events are due largely to the fact that the countries of the treaty of 1889 still have in their local law the provision which gives priority to local creditors in the case of concurrent bankruptcies. It remains to be seen how the criticism of the new treaty rule will affect the future of the priority rule in the local law. ${ }^{79}$ Both issues are interrelated. Growing commercial interrelations should eventually lead to the elimination of the rules.

\section{Special Situations}

The Russian Assets. With the nationalization of Russian banking and insurance companies by the Soviet decrees of 1917 and 1918 , distribution problems arose with respect to the corporate assets outside Russia. If these assets were insufficient to cover the claims of creditors outside Russia, the company was in effect insolvent in so far as such creditors were concerned. Application of bankruptcy principles was indicated for the distribution of the assets. This was done in most countries. ${ }^{80}$

Reference may be made, for example, to the decisions of the French courts in the matter of the Russo-Asiatic Bank. That bank was brought in judicial liquidation, a proceeding analogous to bankruptcy, in the French courts. The question arose whether creditors who had dealt with the bank in Russia and China should be admitted in the distributions in France on equality with the local creditors. The Paris Court of Appeals ${ }^{81}$ ruled that there was no provision in the law permitting differentiation. In so far as the individual creditor has received payments in the liquidation of the Chinese branch, marshalling was prescribed to maintain equality.

The distribution problem would have created no difficulty in the United States, could the federal bankruptcy act have been applied. Banking and insurance corporations, however, are excepted from the bankruptcy act ${ }^{82}$ and are controlled by state law. In the state of New York, a special law was passed in 1936 providing for the appointment of receivers to liquidate local assets of foreign corporations which have ceased to do business or have been dissolved, liquidated, or nationalized. ${ }^{83}$ This law gives the claims a ranking for distribution purposes. Originally, a priority was established for claims which arose or accrued in favor of residents of the state of New York and claims based on causes of action which accrued or arose in the state of New York. ${ }^{84}$ The constitutionality of this provision was questionable in view of an important decision of the Supreme Court of the United States. A statute had been passed in the state of Tennessee giving residents of

\footnotetext{
${ }^{70}$ In Argentina, Dr. Alcorta had suggested in 1924 replacement of the local priority rule by the "separate establishment" rule of the Montevideo Treaty of 1889 ; loc. cit. supra note 47.

${ }^{80}$ For England, e.g., see Cheshre, Private International Law (2d ed. 1938) 15 I and references there.

${ }^{81}$ App. Paris, July 22, 1929 (1929) Journaz DU Drolt Internatnonaz 78, ro95 (with note by Picard); (1930) Revue de Drott Internationaz Prive II4 (with note by Valensi).

${ }^{82}$ U. S. BankRuptcy ACT, \$4, 52 STAT. 845 (1938), II U. S. C. $\$ 22$ (Supp. 1945).

${ }^{83}$ N. Y. Laws 1936, c. 917; N. Y. Crv. Practice Act, $\$ 977-b$.

${ }^{84}$ Subd. 16 (c) of $\$ 977^{-b}$, stipra note 83 .
} 
Tennessee a priority over other creditors in the liquidation of the local assets of foreign corporations. ${ }^{85}$ Regarding creditors from other states of the Union, the statute was declared unconstitutional in Blake v. McClung ${ }^{\mathrm{sc}}$ for violating the Article of the Constitution of the United States which entitles citizens of each state to all privileges and immunities of citizens in the several states. ${ }^{87}$ The New York law of 1936 was amended in $193^{8}$. It now provides priority for claims which accrued or arose in favor of persons residing and corporations organized in the United States or in a state thereof, and for claims based on causes of action which accrued or arose in the state of New York. ${ }^{8 s}$ Under this provision, American citizens and foreigners alike who reside outside the United States and have no New York claims are not paid when the assets are insufficient to pay the other creditors. The constitutionality of the provision has not yet been tested.

This differentiation between creditors is a departure from the traditional policy of the state of New York. Full equality was prescribed as far back as 1775 by a Colonial Act which first gave the possibility of a distribution proceeding for the local assets of a non-resident debtor. ${ }^{89}$ The policy of equal admission of nonresident creditors, particularly stressed in Matter of Bonnaffe, ${ }^{90}$ had been maintained ever since. As late as 1926 , creditor equality was declared to be the policy of the state of New York by the highest court of the state in Matter of People (Norske Lloyd Ins. Co.). ${ }^{91}$ The New York law differs from the federal policy of equal distribution without regard to the place of residence, laid down in the federal bankruptcy act. ${ }^{22}$

It was the problem of the disposition of the Russian assets which led to the New York legislation of 1936 providing for the liquidation of local assets of foreign corporations. This legislation, oddly enough, cannot now be applied to the distribution of the Russian assets because of the Litvinov Assignment and the effect given it by the Supreme Court of the United States in the Pink case.

The Pink Case. As an incident to the recognition of the U. S. S. R. as the de jure government of Russia, the United States Government, in r933, accepted an assignment by the U.S. S. R. of its rights as a successor to the nationalized Russian insurance and banking corporations to the assets in the United States of these cor-

\footnotetext{
${ }^{85}$ Tenn. Laws 1877 , c. $31, \$ 5,3$ Tens. Code ANN. (Williams, r942) \$4r34. Cf. Carpenter v. Ludlum, 69 F. (2d) IgI (C. C. A. 3d, I934).

${ }^{80}$ I72 U. S. 239 (1898). Cf. Goodrich, Conflict of LAws (2d ed. 1938) 521.

${ }^{87}$ U. S. CoNsT. ATt. IV, \$2 (I).

${ }^{88}$ N. Y. Laws I938, c. 604 ; N. Y. Civ. Practice Act, $\$ 977-b$, subd. I6 (c), as amended, 2 LAws op N. Y. (Thompson, 1939) 1744. Cf. Sobel, Civil Practice Act Amendiments (1938) 10 N. Y. St. BAR A. BurL. 73, 81.

${ }^{85}$ N. Y. Act for Relief against Absconding and Absent Debtors, April 3, 1775, c. I73I, 5 N. Y. COLONIAL Laws (I894) 807 .

${ }^{00} 23$ N. Y. I69, I78 (186r). See also Matter of Coates, 3 Abb. App. Dec. 231 (N. Y. I856) for a discussion of N. Y. Rev. Stat., pt. Il, c. V, tit. I, art. First, SI (2), I Rev. Stat. (1836) 764.

${ }^{21} 242$ N. Y. I48, 164, 15I N. E. 159 (1926).

${ }^{03}$ Supra page 699. Commenting on the bankruptcy power under the Federal Constitution, Story warned of the consequences which a preference given to domestic creditors by one state of the Union may have for American citizens in general in regard to their position as creditors abroad. SToRY, op. cit. supra note $\mathrm{X}, 5 \mathrm{I}$ iog.
} 
porations (the "Litvinov Assignment"). Considerable litigation evolved from the claim of the United States Government for the assigned assets. ${ }^{03}$ This litigation is of interest here only in so far as the rights of the creditors of the corporations are concerned.

In the case of the New York branch of the First Russian Insurance Co., the local creditors were paid and payment of the foreign creditors has already been authorized by the New York courts when the United States Government claimed the assets from the New York Superintendent of Insurance who held them as receiver. The Superintendent opposed the claim. One of his arguments was that it was against "due process of law" guaranteed by the Constitution of the United States to bar the payment of the foreign claims. The Supreme Court of the United States, in United States $v$. Pink, ${ }^{95}$ held that the United States is entitled to the property as against the corporation and the foreign creditors. ${ }^{96}$ The decision has been the subject of much discussion and critical comment. ${ }^{97}$

The majority opinion refers to Disconto Gesellschaft v. $U m b r e i t^{88}$ and states that the Federal Government is not barred by the "due process of law" clause of the Constitution from securing for itself and American citizens priority against creditors who are nationals of foreign countries and whose claims arose abroad. "There is no Constitutional reason why this Government need act as the collection agent for nationals of other countries when it takes steps to protect itself or its own nationals on external debts. There is no reason why it may not, through such devices as the Litvinov Assignment, make itself and its nationals whole from assets here before it permits such assets to go abroad in satisfaction of claim of aliens made elsewhere and not incurred in connection with business conducted in this country."

This is the Constitutional aspect of the question involving the interpretation of the "due process of law" clause. ${ }^{100}$ Even greater importance is attached to the political decision by the Executive Branch and the Congress of the United States

${ }^{93}$ Cf. Hollander, Confiscation, Aggression, and Foreign-Funds Control in American Law (1942) 7 ff.; Scheftel, La reconnaissance internationale du Gouvernement Soviétique et ses répercussions sur la jurisprudence américaine (1938) Journal, du Droit INTERnational, 452.

${ }^{2}$ U. S. CONST. AMEND. V.

${ }^{25} 315$ U. S. 203 (194I) (Stone, C. J., and Roberts, J., dissenting); Lauterpacht, AnnunL Digest and Reports of Public International Law Cases ig4I-1942 (1945) 48; (1945) 67-72 Journal du Droit InTERNational 75.

${ }^{\circ 0}$ Applied in Steingut v. Guaranty Trust Co. of New York, 58 F. Supp. 623 (S. D. N. Y. 1944) (assets of the Russo Asiatic Bank).

${ }^{87}$ See, e.g., Borchard, Extraterritorial Confiscations (1942) $3^{6}$ AMr. J. INT. L. 275; Jessup, The Litvinov Assignment and the Pink Case (1942) 36 AM. J. INT. L. 282; Cheatham, Obseruations an sujet de la décision rendue par la Cour Stuprême des Etats Unis dans l'affaire United States v. Pink (1945) 67-72 Journal du Droit International 48; Note (x942) 5I Yale L. J. 848.

${ }^{88}$ Stspra page 699 (a state policy was upheld preventing creditors from abroad from taking assets out of the state for distribution abroad; no question of a distribution order was involved for distributions within the state).

${ }^{\circ 0} \mathrm{Mr}$. Justice Douglas, speaking for the majority, 315 U. S. at 228.

100 "'The only general principle for interpreting this 'due process of law' clause would appear to be this: Legislation which appeals to the majority of the Supreme Court as shockingly unfair to the individuals affected is unconstitutional." Wm. Draper Lewis, Human Rights in England and the United States (1946) 243 ANNAls 60, 63. 
regarding the ultimate disposition of the corporate assets and the payment of the foreign claims. A fundamental question of policy is involved.

Seized Enemy Assets. Distribution problems similar to those in the matter of the Russian assets arose after the First World War with regard to seized enemy private property. ${ }^{101}$ These problems now appear again. ${ }^{102}$ If the local assets are insufficient to pay the claims of all non-enemy creditors, their equal distribution appears indicated.

Public Debts. The recognition of the principle of creditor equality is less firmly established in public than in private law. This was evidenced by the decision of the Hague Permanent Court of Arbitration in 1904 in the Venezuelan Preferential Claims case. The question was whether the three countries, Germany, Great Britain, and Italy, which had blockaded Venezuela for non-payment of its foreign debts, were to be paid before the non-blockading creditor countries out of the revenues to be set aside by Venezuela for the payment of the foreign debts. The Tribunal held ${ }^{103}$ that, because the three powers had asked for priority and Venezuela had not objected, they were entitled to it. The decision has been called "bad both in law and morals."104 Actually, it gave a premium to the use of force and war. The general disapproval of the decision ${ }^{105}$ may indicate a growing recognition of the principle of creditor equality also in public law. ${ }^{106}$

\section{REMEDIES}

The situations here discussed demonstrate that instances of differentiation and discrimination against distant creditors are not infrequent. Regarding creditor equality, the stage has obviously not yet been reached where it is generally recognized that "we cannot successfully cooperate with the rest of the world in establishing a reign of law unless we are prepared to have that law sometimes operate against what would be our national advantage."107

Infringements of the rule of equality have created a feeling of general insecurity in foreign trade. Creditors demand special guaranties for fear that their rights may

\footnotetext{
101 See Hays, Enemy Property in America (r923) 3x; Rabel, Situs Problems in Enemy Property Measures (1945) II LAW \& Contemp. Prob. II8, I32. Cf. in re Wiskemann, 92 L. J. Ch. 349 (I923).

${ }_{102}$ Cf. Domke, Trading with the ENEMY IN WoRLd WAR II (1943) 307; Littauer, The Unfreezing of Foreign Funds (1945) 45 CoL. L. REv. 132, 160; Rubin, "Inviolability" of Enemy Private Property (r945) in LaW \& Contemp. Prob. I66, I79 note 42 (b); Paris Agreement on Reparations, esp. Art. 6A and Res. No. 3 (Jan. 27, I946) I4 Dep't of State Bull. II4, II7, 122.

${ }^{203} 7$ Moore, Digest of International Law (1906) II8, (1908) 2 AM. J. INT. L. 907, 2 Journal du Droit International, Tables I874-1904 (1905) II39; Scott, The Hague Court Reports (I9I6) 55. 104 Hershex, Essentials of International Public Law (Rev. ed. I927) 474, note 2.

${ }^{100}$ Sce, c.g., I Scott, The Hague Peace Conferences of 1899 and 1907 (1908) 39i; Fischer Williams, Chapters on Current International Law and the League of Nations (i929) 322; Hudson, International Tribunals (I944) I3I; I Schwarzenberger, Internattonal Law (i945) 239; Mallarmé, L'Arbitrage Vénézuélien devant la Cour de la Haye (Ig06) I3 Revue Générare de DroIT International Public 423.

${ }^{106}$ Professor Borchard notes as a circumstance where intervention may be legitimate: when foreign creditors are illegally treated, especially if they are discriminated against in favor of national creditors, or if certain categories of creditors are preferred to others. Borchard, Diplomatic Protection of Crtizens ABROAD (1915) 312.

${ }^{107}$ Mr. Justice Jackson, The Rule of Law among Nations (Address) AM. Soc. INT. L., Proceedings (1945) 18 (Washington Meeting, April 13-14, I945), also in (1945) 31 A. B. A. J. 290, 294.
} 
be curtailed by a local priority rule. Domestic trade cannot be conceived without a system guaranteeing all creditors equal treatment in bankruptcies. International trade requires the same security. This security is lacking.

There are many means to improve the situation. As there are various types of differentiation and discrimination, the same remedies cannot be applied to all cases. One measure, however, can be considered in all situations. If proper publicity is given to all violations of the equality rule, the discriminatory rules in all likelihood will disappear and violations will become less frequent.

Diplomatic protection, when there is a denial of justice, and retaliation are among the legal remedies. In some countries, retaliation is automatic, as the law provides that foreign creditors are admitted on equal terms only if their home country does likewise. ${ }^{108}$ There can be little doubt that absence of retaliation is responsible for the survival of some of the local priority rules. The local creditors have the benefit of the rule without being submitted to corresponding treatment abroad.

A preventive measure has been the inclusion of a clause in international agreements guaranteeing equal treatment in bankruptcy proceedings to the nationals of the contracting states. Such a clause is found in a number of treaties of Friendship and Commerce, in treaties on Judicial Assistance, and other treaties. ${ }^{100}$ It would seem that this clause should always be included in treaties of Friendship and Commerce. ${ }^{110}$ The wording of the clause is important in view of the fact that differentiation against the foreign creditor is not based on nationality exclusively. The following text may be appropriate:

The Nationals of each of the High Contracting Parties shall enjoy equal rights in bankruptcy, arrangement, and similar proceedings, regardless of their place of residence and the location of their claim.

The danger of creditor differentiation has been eliminated at the source ${ }^{111}$ by bankruptcy treaties providing for a single administration of all the assets and their equal distribution among all creditors. There are at present many of these treaties. ${ }^{112}$ Fifteen Latin-American countries are bound by the Bustamante Code. The Scandinavian Bankruptcy Convention covers all Scandinavian countries. Numerous treaties exist in Central Europe between Austria, Czechoslovakia, Yugoslavia, Hungary,

\footnotetext{
${ }^{108}$ E.g., the bankruptcy laws of Austria ( $\left.\$ 58\right)$, Czechoslovakia, Yugoslavia, Hungary ( $\$ 71$ ), 28 Commercisl LAWS OF THE WORLD 154 .

${ }^{108}$ E.g., treaty between Switzerland and Italy of July 22, 1868, on Establishment and Consuls, $\$ 8$, 3 Wolf, Schweizerische Bundesgesetzgebung (2d ed. igo8) 6r4; Convention between Bulgaria and Rumania of April I9, I924, on Judicial Assistance, $\$$ I (4), 33 League of Nations Treaty Series 211; the treaties between Czechoslovakia and Lithuania, and Czechoslovakia and Poland, supra note 13.

${ }^{110}$ The customary clauses in these treaties do not always protect against discrimination in bankruptcy. See Wigmore, A Guide to American International Law (ig43) i8 i for the text of such a treaty.

111 "Of course, the practical impossibility of doing equity between creditors in a fragmentary administration should be sufficiently obvious." McLaughlin, Book Review (1936) 50 Harv. L. REv. 380.

${ }^{112}$ Cf. Nadelmann, Bankruptcy Treaties (1944) 93 U. of PA. L. Rev. 58.
} 
and Bulgaria. Likewise, the Netherlands and Belgium, Belgium and France, France and Switzerland, France and Italy, Italy and Yugoslavia, are bound by bankruptcy treaties. ${ }^{113}$

Many efforts have been made to secure equal treatment for the distant creditor on a world-wide basis. Resolutions have been passed by many international conferences stressing the principle of creditor equality. ${ }^{114}$ The Hague Conferences on Private International Law, ${ }^{115}$ the Institute of International Law, ${ }^{116}$ and the International Law Association ${ }^{117}$ have strived toward the same goal in attempting to secure the conclusion of a general bankruptcy convention. The Economic Committee of the League of Nations, in its draft convention for the International Conference on the Treatment of Foreigners dealt with the protection of the non-resident as well as the resident foreigner. ${ }^{118}$ Recently, the International Chamber of Commerce considered the subject of creditor differentiation ${ }^{112}$ and adopted a resolution urging the conclusion of international conventions to secure creditor equality. ${ }^{120}$

With the creation of the United Nations, the Economic and Social Council has become the logical place for a common and systematic effort to do away, once for all, with creditor discriminations. Acting as trade barriers, these discriminations constitute an international problem of economic character coming under the jurisdiction of the Council. ${ }^{121}$ The International Trade Organization, if created as contemplated, ${ }^{122}$ would be the specialized agency competent to deal with the subject. Should a study of it be decided upon, it would induce all governments to review their own legislation and could thus expedite the disappearance of the local priority rules.

The coming International Conference on Trade and Employment has on its agenda the conclusion of an international agreement relating to regulations, restrictions, and discriminations affecting international trade..$^{123}$ One may hope that due consideration will be given to discriminations against distant creditors. Great prog-

${ }^{113}$ References in Nadelmann, supra note 112. Treaty between Italy and Yugoslavia of August 12, 1924: 82 League of Nations Treaty Series 356.

116 E.g., International Congress of Commerce and Industry, Paris, I889 (1892) Journal du Droir INTERNATIONAL III9 (report Contuzzi at II05).

${ }^{125}$ See, notably, Draft Convention of 1925, Actes de la 5E ConfÉrence de Droit INternational Privt (I925) 34I; (1926) Journal du Droit International 822; (I944) 93 U. of Pa. L. Rev. 94 (trans.).

${ }^{210} 13$ ANNUARe de I'INSTitut de Droit International (1894) 279; 25 ANnuaire (I912) 670; (1894) Journal du Droit International 608; (1913) id. 73 I.

${ }^{117}$ International Law Ass'N, 7TH Report (London, 1879) 295; id., 37th Report (Oxford 1932) 288; id., 39TH REPORT (Paris 1936) 226.

${ }_{118}$ LeAGUe of NAtions, J. O. (1928) 1004; Document, c. 36. M.21. 1929. II, I6.

${ }^{110}$ See Leveque report (1939) Annales de Droit Commercial Français, Etranger er Internationat, SupplEMeNt No. 3, to (the investigation was confined to discrimination based on nationality).

${ }^{220}$ Loc. cit. supra note 12.

121 Charter of the United Nations, c. I, art. I (3), c. X, art. 62.

${ }^{139}$ See Dep't of State, Proposals for Expansion of Wordd Trade and Employment (Publication 2411, Commercial Policy Series 79, 1945); Hyde, The American Trade Proposals: An International Trade Organization (1946) I4 Dep't of State Bull. 6 I6.

${ }^{133}$ United Nations, Economic and Social Council, Resolution of Feb. 18, 1946, relating to proposed General World Conference on Trade and Employment, (1946) I4 Dep'i of State Bull. 326. 
ress would be achieved if a clause against creditor discrimination were included in an international agreement on principles of fair trade. Should recourse be open to an international tribunal ${ }^{124}$ in the case of violation of a "principle," creditors everywhere would find the security which an American creditor has within the United States against discriminatory state ${ }^{125}$ legislation. Protection against creditor discrimination would be established internationally.

124 Cf. Hudson, International Tribunals (1944) 213; Timberg, An International Trade Tribunal (1945) 33 Geo. L. J. 373; Section of International and Comparative Law, American Bar Association, Resolution of April 27, 1946 , for Establishment of a Permanent International Trade Tribunal.

${ }^{125}$ Blake v. McClung, stura p. 707. 